\title{
PENERAPAN MODEL USAHATANI SEHAT MELALUI PENGGUNAAN PUPUK SILIKAT PLUS PADA TANAMAN KAKAO DI KECAMATAN GANGGA KABUPATEN LOMBOK UTARA
}

\author{
Mulyati1), Joko Priyono1), Muliatiningsih ${ }^{2)}$ \\ 1) IImu Tanah, Fakultas Pertanian, Universitas Mataram, Mataram, NTB, Indonesia \\ 2)Teknik Pertanian, Fakultas Pertanian, Universitas Muhammadiyah Mataram, Mataram, NTB, Indonesia \\ Corresponding author : Mulyati \\ E-mail : yatimulyati@unram.ac.id
}

Diterima 17 Oktober 2020, Disetujui 25 Oktober 2020

\begin{abstract}
ABSTRAK
Tujuan kegiatan pengabdian kepada masyarakat (PKM) ini adalah memberikan pengetahuan dan pelatihan kepada petani kakao tentang teknik usahatani kakao yang sesuai dengan standard praktik pertanian yang baik atau Good Agriculture Practices (GAP); dan memperkenalkan konsep usahatani sehat kepada petanik melalui penggunaan pupuk silikat plus (SiPlus). Kegiatan PKM dilakukan melalui penyuluhan secara langsung dengan cara memutarkan video tentang penerapan GAP untuk tanaman kakao dan slide tentang konsep dan penerapan bertani sehat dengan menggunakan pupuk SiPlus di balai desa Genggelang, Kecamatan Gangga, Kabupaten Lombok Utara. Kegiatan ini dihadiri oleh 21 orang petani dan staf desa serta beberapa tokoh masyarakat yang ada di desa tersebut. Tayangan video tentang GAP kakao difokuskan pada penerapan PSP2S (Panen sering, pemangkasan, pemupukan dan sanitasi). Hasil kegiatan menunjukkan bahwa tayangan video tersebut telah memberikan motivasi bagi petani kakao tentang teknik pengelolaa kebun kakao yang baik. Penggunaan Siplus merupakan metode baru, sehat dan ramah lingkungan. Secara umum, petani sangat antusias dan menyambut baik ajakan tim PKM untuk menerapkan GAP kakao dan konsep bertani sehat dengan SiPlus. Sebagai tindak lanjut dari kegiatan ini, kombinasi metode GAP dan penerapan model usahatani sehat menggunakan Si Plus direkomendasikan untuk dapat dijadikan sebagai model usahatani kakao di KLU serta dapat disebar-luaskan ke petani kakao lainnya.
\end{abstract}

Kata kunci: model usahatani; silikat plus; kakao.

\begin{abstract}
The purpose of this community service (CS) was to provide knowledge and traning to cocoa farmers that are in accordance with good Agriculture practices (GAP) standard; and introducing the concept of healthy farming through the use of silicate plus fertilizer $(\mathrm{Si}$ plus $)$. This activities are carried out through direct counseling by playing a video about the application of GAP for cocoa plants and a slide about the concept of healthy farming using $\mathrm{Si}$ plus fertilizer. The activity was held at the Genggelang village hall. Gangga District, Noth Lombok Regency, with 21 farmers attended and village staff as well as several community leaders in the village. The video presented about GAP for cocoa is focused on implementing PSP2S (frequent harvesting, pruning, fertilizing and sanitation). The results showed that the video was motivated cocoa farmers about good cocoa garden management techniques and synergistic manner. In general, the farmes were very enthusiastic and welcome the community service team's invitation to apply GAP for cocoa and the concept of healthy farming with Siplus . To follow-up this activity, a combination of the GAP and applying Siplus is recommended to be used as a cocoa farming model in North Lombok Regency and it can be distributed to other cocoa farmers.
\end{abstract}

Keywords: farming model; silicate plus; cocoa.

\section{PENDAHULUAN}

Komoditi kakao atau coklat telah dikenal sebagai komoditi penting di dunia; dan di Indonesia, termasuk di Kabupaten Lombok Utara (KLU), kakao merupakan komoditi unggulan dalam program pengembangan sektor pertanian (Tresliyana et al., 2004); (Rubiyo \& Siswanto, 2012). Di KLU, luas areal tanam sekitar 3.000 ha, tetapi produktivitas dan profitabilitas usaha tani komoditi itu sangat rendah karena beberapa hambatan yang terkait dengan aspek teknis usaha tani (Saloko et al., 2018).

Masalah serius dan umum adalah serangan dan penyakit. Hama utama yang menyerang tanaman kakao yang dapat 
menurunkan produksi kakao secara signifikan antara lain Cocoa Pod Borer (CPB) atau Cocoa Moth yang disebabkan oleh insek Conopomorpha cramerella, dan Helopeltis spp sebagai penyebab kerusakan buah, sedangkan penyakit utama pada tanaman kakao di Lombok adalah Vascular Streak Dieback (VSD) yang disebabkan oleh Oncobasidium theobromae (Indriani \& Chanan, 2011). Penyakit yang tampak jelas secara visual adalah becak hitam pada buah (Black pod) yang disebabkan jamur (basidiomycete) moniliophthora roreri, dan busuk akar disebabkan pleh jamur Phytophthora spp. Oleh sebab itu, upaya pengembangan kakao lebih difokuskan untuk mengatasi masalah tersebut (Hawa et al., 2015); (Armengot et al., 2020).

Sejauh ini, masalah hama dan penyakit pada kakao diatasi terutama dengan menggunakan pestisida sintesis yang bersifat membunuh hama dan pathogen. Tetapi cara tersebut belum dapat mengatasi masalah itu secara tuntas, bahkan cenderung bertambah parah. Karena kakao adalah produk pangan, harus dihindarkan dari pengaruh/residu pestisida yang bersifat racun bagi konsumen. Oleh karena itu, perlu dicari alternative solusi yang lain yang lebih efektif dan aman bagi konsumen maupun lingkungan.

Konsep usaha tani yang dinilai efektif adalah menyehatkan tanamannya dengan pasokan unsur hara yang cukup dan berimbang sehingga tanaman itu tahan terhadap serangan hama maupun pathogen penyebab penyakit itu, bukan membunuh hama atau pathogen tersebut dengan mengguankan pestisida sintesis yang sudah terbukti tidak tepat/efektif. Salah satu produk yang sangat potensial dapat digunakan untuk menerapkan konsep usahatani tersebut adalah SiPlus Pestisida nabati dibuat dari bahan alami (tanaman), hanya digunakan sebagai pencegah, pengendali mortalitas, bukan pembunuh hama dan penyakit.

Pupuk SiPlus mengandung semua unsur hara esensial bagi tanaman dalam jumlah yang cukup dan berimbang, sehingga aplikasi Si $i^{\text {Plus }}$ akan menjamin pertumbuhan tanaman yang optimal. Selain itu, SiPlus mengandung unsur silikat $(\mathrm{Si})$ yang relative tinggi. Banyak peneliti (Bélanger et al., 2003); (Yukamgo \& Yuwono, 2007); (Khaerana \& Gunawan, 2019) membuktikan bahwa apliaksi Siplus antara lain dapat meningkatkan daya tahan tanaman terhadap serangan hama dan penyakit. Uji multi lokasi (beberapa tempat di Lombok Timur dan Sumbawa), Apliaksi Silus pada tanaman pangan (padi, jagung, dan bawang merah) menunjukan peningkatan produksi tanaman yang signifikan dan penurunan drastis munculnya serangan hama dan penyakit pada tanaman tersebut (Priyono, 2014; data belum/tidak dipublikasikan). Berdasarkan fakta tersebut, SiPlus kemungkinan besar juga dapat digunakan untuk mengatasi masalah serangan hama dan penyakit pada tanaman kakao.

Secara umum permasalahan yang dihadapi petani kakao adalah belum memahami dan menerapkan tentang GAP (good agriculture practice) secara penuh dalam kegiatan usahataninya, sedangkan masalah spesifik adalah serangan hama dan penyakit pada kebun kakao yang dimiliki petani. Dengan demikian solusi yang ditawarkan adalah penjelasan melalui video dan penerapan di lapang tentang GAP dan belajar dari petani kakao sukses di daerah atau tempat lain, dan penerapan konsep bertani menggunakan $\mathrm{Si}^{\text {Plus }}$.

Tujuan utama dari kegiatan pengabdian kepada masyarakat ini adalah untuk mensosialisasikan tentang penggunaan Pupuk Silikat Plus (SiPlus), meningkatkan pengetahuan dan pengalaman kepada petani kakao di Desa Genggelang, Kecamatan Gangga, KLU mengenai teknik usahatani kakao secara umum, belajar dari pengalaman petani kakao yang telah berhasil/sukses dari daerah lain.

Hasil kegiatan pengabdian kepada masyarakat ini diharapkan dapat bermanfaat bagi banyak pihak. Selain manfaat lansung bagi petani sasaran, hasil dari kegiatan dapat dijadikan refrensi untuk diterapkan/diperluas penerapannya pada kelompok tani kakao lain di Lombok maupun daerah lain. Bagi Pemda setempat, kegiatan ini merupakan salah satu upaya untuk mempercepat keberhasilan program pengembangan kakao di KLU. Bagi tim pelaksana Unram, kegiatan ini merupakan sarana untuk menambah pengetahuan/wawasan mengenai masalah on farm dan cara menanganinya yang tepat, serta proses pembelajaran bagi mahsiswa yang dilibatkan dalam kegiatan ini.

\section{METODE}

Kegiatan pengabdian kepada masyarakat ini dilaksanakan dalam dua bentuk kegiatan, yaitu penyuluhan kepada kelompok tani kakao di Desa Gengggelang terkait budidaya tanaman kakao melalui pemutaran video, slide show, dan diskusi di ruangan (khas), dilanjutkan dengan program aksi dan praktik lapang. Pada akhir program dilakukan evaluasi tentang penerapan program ini oleh kelompok tani sasaran.

Materi penerangan meliputi teknis bercocok tanam kakao secara umum, pengenalan pupuk SiPlus dan teknik 
penggunaanya pada tanaman kakao, Alat penerangan yang digunakan berupa video dan slide show yang ditayangkan melalui LCD. Materi sekolah lapang adalah penerapan GAP uasahatani kakao di masing-masing lahan petani antara lain berkaitan dengan sanitasi, pemangkasaan, dan pengguanaan pupuk SiPlus. Bimbingan teknis dari tim pelaksana pengabdian kepada masyarakat dilakukan langsung di lapang, dengan melakukan kunjungan rutin selama enam (6) bulan.

\section{HASIL DAN PEMBAHASAN Kegiatan Sosialisasi dan Penyuluhan}

Sosialisasi tentang program pengabdian kepada yang dilakukan oleh tim pengabdian kepada masyarakat dari Unram,dilanjutkan dengan pemutaran video tentang managemen (penerapan GAP-good agriculture practice), serta penjelasan mengenai pupuk Silikat Plus (SiPlus) dan teknik penggunaanya pada tanaman kakao. Kegiatan itu dilakukan di Gedung Pertemuan Desa Genggelang, Kecamatan Gangga, KLU, dihadiri oleh 26 petani dan beberapa Perangkat Desa Ganggelang.

Kegiatan pengabdian kepada masyarakat ini pada dasarnya adalah memberikan penerangan tentang bagaimana berusahatani kakao yang baik dengan belajar dari pengalaman petani kakao di tempat lain yang telah berhasil, dan mengintrodusir konsep bertani sehat serta teknik penerapannya dengan Silikat $\mathrm{Si}^{\text {Plus }}$ untuk mengatasi masalah teknis (Serangan hama penyakit dan peningkatan kuantitas dan kualitas produksi) usahatani kakao. Kedua masalah utama dalam produksi kakao, yaitu serangan hama penyakit dan pemenuhan kebutuhan unsur hara (pemupukan) kakao, merupakan dua aspek teknis usahatani yang saling terkait . Oleh karena itu, penanganannya harus dilakukan secara terpadu dan sinergis (Lestari et al., 2013).

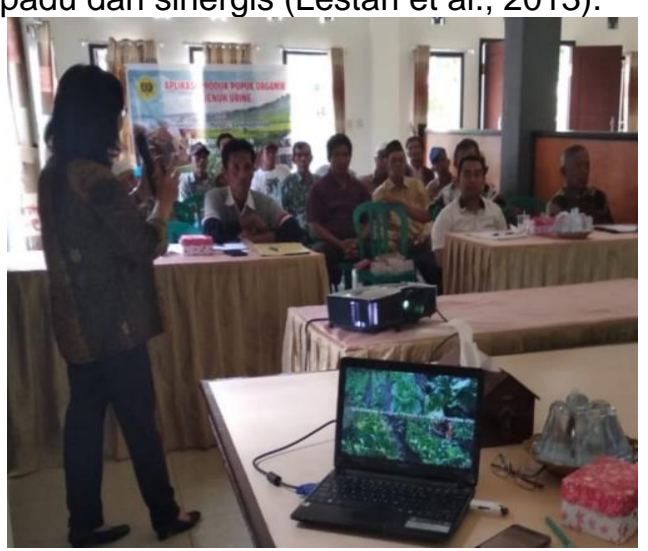

Gambar 1. Penyuluhan budidaya kakao

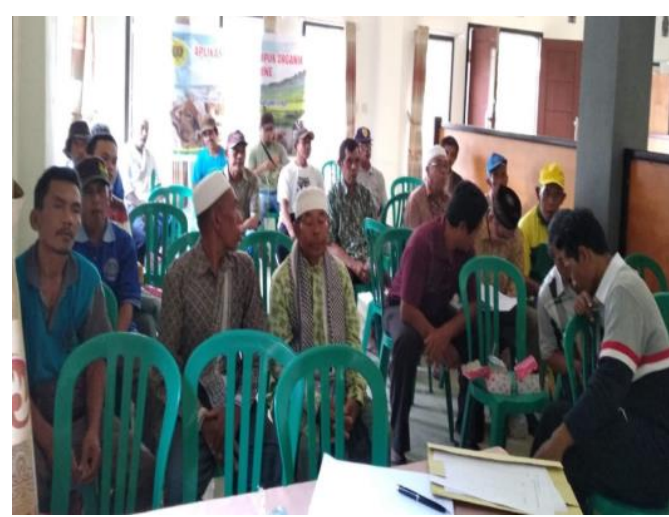

Gambar 2. Peserta mendengar dan menyimak

\section{Pemutaran Video Good Agriculture Practice} Beberapa penyebab menurunnya produksi dan kualitas produksi kakao di Indonesia saat ini adalah :

(1) Teknik budidaya kakao yang kuran tepat sehingga produksi buah kakao belum optimal

(2) serangan hama penyakit (PBK, penggerek buah kakao), helopeltis, penggerek batang, busuk buah, kangker batang, dan VSD (Vascular Streak Dieback),

(3) menuanya pohon kakao

(4) klon yang jelek secara genetik

(5) penanganan pasca panen yang buruk.

Tanaman kakao dapat tumbuh subur pada daerah dengan curah hujan yang merata sepanjang tahun, tumbuh pada ketinggian 0 $600 \mathrm{~m} \mathrm{dpl}, \mathrm{pH}$ tanah berkisar dari 6,5 - 7,0, dengan suhu (21-32 $\left.{ }^{\circ} \mathrm{C}\right)$, ketersediaan air, kelembaban dan sinar matahari yang berimbang. Hal ini dapat dilakukan dengan mengatur kelembaban dan intensitas matahari melalui pengaturan pohon pelindung dan pemangkasan secar teratur, sehingga proses fotosintesis dapat berlangsung dengan baik.

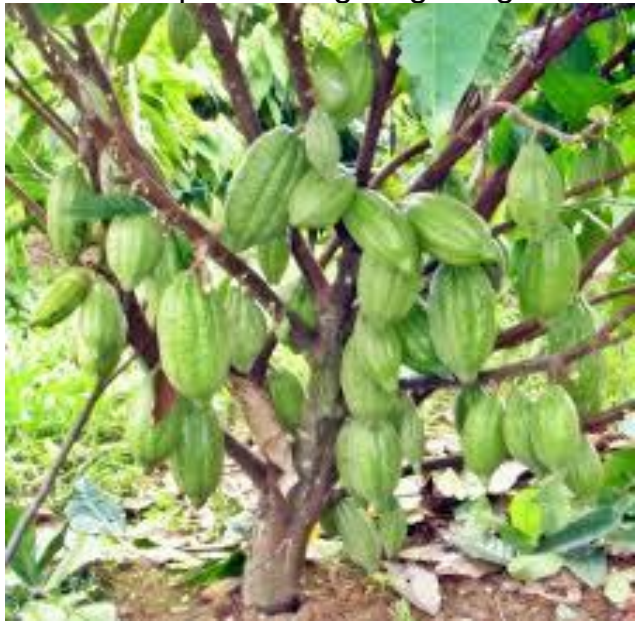

Gambar 3. Buah coklat muda 


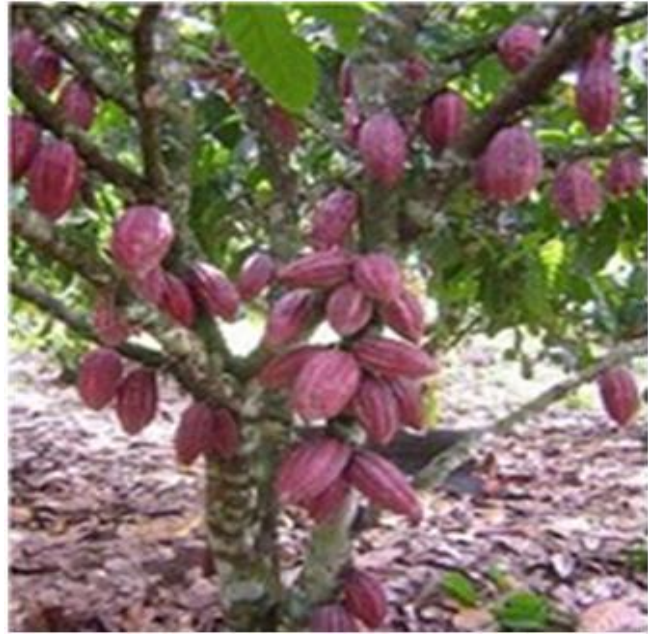

Gambar 4. Buah coklat tua

Tanaman kakao yag dibudidayakan dengan baik akan memberikan buah yang baik. Gambar 3 menunjukkanr buah kakao yang masih muda dan gambar 4 menunjukkan buah kakao yang mulai tua. Umumnya tahap pertumbuhan tanaman kakao dibagi menjadi 2 fase, yakni fase vegetatif dan fase generatif.

Pada fase vegetatif, terjadi pada perkembangan akar, daun dan batang, terutama pada awal perkembangan akar,daun dan batang baru,terutama saat awal pertumbuhan atau setelah usai masa berbunga atau berbuah. Pada fase ini terjadi tiga proses penting,yakni pembelahan sel, perpanjangan sel, dan tahap pertama dari diferensiasi sel. Sedangkan pada fase generatif terjadi pada pembentukan dan perkembangan kuncup-kuncup bunga,bunga,buah dan biji. Dapat juga terjadi pada pembesaran dan pendewasaan struktur penyimpanan makanan, akar-akar dan batang yang berdaging. Proses penting ynag berlangsung pada fase generatif meliputi pembuahan sel-sel yang secara relative berjumlah sedikit; pendewasaan jaringan; penebalan serabut-serabut; pembentukan hormone untuk perkembangan kuncup bunga,bunga,buah dan biji; perkembangan alat-alat penyimpanan; dan pembentukan koloid-koloid hidrofilik(koloid yang dapat menahan air).

Terkait dengan berbagai permasalahan tersebut, fokus dari sisi video GAP ini adalah menunjukan kepada petani kakao mengenai penerapan metode PsP2S (Panen sering, Pemangkasan, Pemupukan, dan Sanitasi).

Pemanenan yang sering, dimaksudkan untuk menghindarkan terjadinya pembusukan buah (serangan PBK) yang sudah masak. Sambil memanen, buah yang diserang hama dan/penyakit harus segera dipetik (dibersihkan dari pohon) dan ditimbun di dalam tanah sehingga tidak menular. Panen sering merupakan langkah awal yang penting untuk menjamin keberhasilan usahatani kakao

Pemangkasan, dilakukan secara rutin untuk mengurangi efek naungan yang berlebihan, mengurangi dahan yang tumpang-tindih, serta cabang yang tidak produktif, sehingga tanaman dapat menerima cukup penerangan (cahaya matahari) dan untuk mengurangi kelembaban di sekitar pohon yang dapat menjadi serang hama, virus, dan berkembangnya jamur yang merugikan tanaman kakao (Tutiliana, 2016); (Winarsih, 1990).

Pemupukan, Kakao termasuk jenis tanaman yang membutuhkan unsur hara yang lengkap untuk pertumbuhan dan produksi yamg optimal. Kekurangan atau defisiensi salah satu hara yang esensial menyebabkan produktivitas tanaman kakao menjadi rendah. Oleh karenaitu, pemberian pupuk haruslah berimbang antara hara makro dan hara mikro. Pemupukan kakao dengan $\mathrm{N}, \mathrm{P}$, dan $\mathrm{K}$ diberikan melalui tanah minimal setahun sekali, yaitu menjelang musim hujan. Kakao yang mendapat pasokan masukan (unsur hara) yang cukup, dilakukan melalui pemupukan, akan menjamin produksi yang tinggi (Firmansyah, 2010) .

Sanitasi, untuk menghindarkan adanya serangan hama dan penyakit pada kakao, sanitasi (kebersihan) kebun kakao sangat penting dilakukan secara rutin. Kulit kakao, dahan, ranting, dan daun yang menumpuk di sekitar tegakan tanaman kakao, harus dibersihkan/dipendam ke dalam tanah di sekitar larikan tanaman kakao (Rosada, 2016).

Penanganan pasca panen merupakan bagian sangat penting, agar produk kakao yang diperoleh petani berkualitas tinggi, sehingga mendapatkan harga tertinggi. Namun, dalam kegiatan ini, pemutaran video khusus untuk penanganan pasca panen tidak dilakukan karena kegiatan ini lebih difokuskan pada upaya peningkatan produksi melalui perbaikan teknis pengelolaan tanaman kakao (Fallis, 2013).

\section{Penerapan Good Agriculture Practices}

Peningkatan pengetahuan dan teknologi budidaya kakao untuk masyarakat petani sangatlah penting terutama dalam menjawab fenomena global demi terciptanya kesinambungan produksi kakao melalui suatu program yang disebut Sustainability Coco Production Program. Disamping menjaga kesinambungan produksi tanaman kakao, program ini juga berorientasi pada kelestarian lingkungan. 
Upaya lain yang juga dapat ditempuh dalam meningkatkan produksi kakao adalah dengan memanfaatkan bahan tanaman unggulan seperti melalui sambung pucuk dan sambung samping, menjaga kesuburan tanah baik secara fisik, kimia dan biologi tanaman.

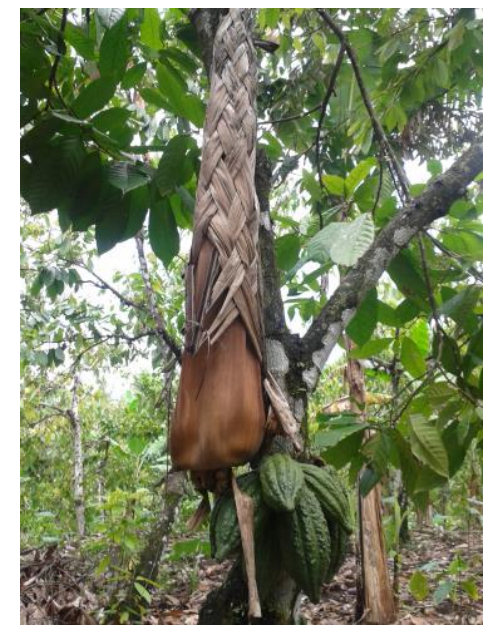

Gambar 5. Pemanfaatan musuh alami dalam penanganan HPT

\section{Konsep Usahatani Sehat dengan SiPlus}

Konsep usahatani kakao sehat serta teknologi aplikatifnya dijelaskan oleh tim pelaksana PPM kepada peserta (petani kakao) secara lansung dengan bantuan 'slide' yang ditayangkan melalui LCD. Pada prinsipnya, konsep bertani sehat tersebut dimaksudkan untuk menangani masalah teknis usahatani kakao secara terpadu dan sinergis, terutama yang berkaitan dengan serangan hama dan penyakit tanaman (HPT) dan pemenuhan kebutuhan unsur hara (pemupukan) secara bijak, mudah dan efektif, serta ramah lingkungan. Kosep itu telah diterapkan pada usahatani tanaman kakao, tetapi pada usahatani kakao belum pernah dilakukan sebelumnya.

Terdapat 3 prinsip dasar pada konsep usahatani sehat tersebut, yaitu (1) serangan HPT tidak diatasi dengan cara membasmi/membunuh organisme (hama dan pathogen) dengan menggunakan pestisida sintetis yang bersifat racun (membunuh) bagi oragnisme, tetapi diatasi dengan cara meningkatkan daya tahan tanaman terhadap serangan HPT yang berat, (2) sebagai upaya pencegahan terhadap terjadinya serangan HPT yang berat, hanya digunakan pestisida nabati bahan bakunya dari bahan tanaman local, (3) kebutuhan hara tanaman dipasok (dipenuhi) dengan pupuk berunsur hara esensial lengkap dan berimbang, diaplikasikan secara lansung pada tanamannya, bukan melalui tanah (media tumbuh tanaman). Ketiga prinsip itu, secara teknis, diterapkan pada usahatani kakao melalui penggunaan pupuk Silikat Plus (Si $\left.{ }^{\text {Plus }}\right)$ dan dikombinasikan dengan pestisida nabati.

Pupuk SiPlus adalah pupuk organo mineral cair berkadar hara esnsial lengkap dan unsur silikat ( $\mathrm{S}^{\text {Plus }}$ ) terlarut yang cukup tinggi, dibuat dari batuan silikat/vulkanik, diproses melalui teknologi nano tanpa menggunakan bahan kimia sintesis bereaksi keras. Pupuk Si Plus diaplikasikan langsung pada tanaman, yaitu disemprotkan melalui daun, batang/dan buah, atau dengan metode in push pada batang bagian bawah $(0,5-1 \mathrm{~m}$ di atas permukaan tanah). Hasil uji coba aplikasi SiPlus pada kakao, baik melalui metode semprot ataupun in push, yang telah dilakukan (Priyono et al., 2014) di KLU dan Lombok Timur menunjukan (a) penurunan intensitas serangan hama dan penyakit (helopeltis, PBK, dan VSD) yang signifikan, (b) meningkatkan jumlah buah serta kualitas/bobot biji kakao, dan (c) meransang/percepatan pebuangan, serta pertumbuhan cabang dan daun tanaman, terutama tanaman yang masih muda. Untuk memperoleh hasil yang maksimal, direkomendasikan untuk mengaplikasi Siplus sejak dini (fase pertumbuhan awal bahkan pada tahap pembibitan).

\section{Respon/Tanggapan Petani}

Secara umum, tanggapan petani peserta kegiatan pengabdian kepada masyarakat ini sangat positif, mereka sangat antusias untuk segera menerapkan konsep yang disampaikan pada pertemuan tersebut. Selama ini, petani kakao di KLU tidak pernah mendapatkan pencerahan atau bimbingan lapang secara lansung dari pihak (dinas) terkait atau pihak lain, sehingga mereka tidak tahu apa yang harus diperbuat untuk menangani permasalahan usahatani kakao yang mereka lakukan, terutama masalah serangan hama dan penyakit. Mereka bersedia menindak-lanjuti/menerapkan teknis GAP dan penggunaan $\mathrm{Si}^{\text {Plus }}$ mulai awal musim hujan yang akan datang (umumnya sekitar bulan November/Desember).

\section{Kaji Terap Usahatani Sehat pada Kakao}

Menindak-lanjuti kegiatan penyuluhan seperti diuraikan di atas, telah dilakukan observasi dan pertemuan kecil di lapangan/kebun dengan beberapa kelompok tani kakao di Desa Genggelang, dalam rangka pelaksnaan kaji terap penggunaan $\mathrm{Si}^{\text {Plus }}$. Sebagai langkah persiapan aplikasi Si ${ }^{\text {Plus }}$, GPA harus terapkan, terutama terkait dengan pemangkasan dan sanitasi kakao yang akan 
dipupuk SiPlus. Kegiatan tersebut sedang berlansung dan belum dilaporkan hasilnya.

\section{SIMPULAN DAN SARAN}

Kegiatan pengabdian kepada masyarakat ini mempunyai peranan penting untuk petani kakao dalam mengembangkan usahataninya terutama petani kakao di kabupaten Lombok Utara. Peserta penyuluhan Petani menyambut baik arahan dan ajakan tim pengabdian kepada masyarakat untuk dapat menerapkan good agriculture practices (GAP) dan apliaksi SiPlus di kebun kakao masing-masing. Penyampaian materi dengan tayangan video tentang 'good agriculture practice' atau GAP kakao difokuskan pada penerapan PsP2S (panen sering, pemangkasan, pemumpukan, dan sanitasi) sangat menarik perhatian peserta penyuluhan. Tayangan tersebut memberikan pengetahuan yang sangat berarti bagi petani kakao tentang bagaimana mengelola kebun kakao yang baik. Sedangkan untuk materi penggunaan Silus merupakan metode baru, sehat dan ramah lingkungan, untuk mengatasi permasalahan umum pada tanaman kakao, yaitu serangan hama dan penyakit dan produktivitas kakao secara terpadu dan sinergis.

Dari pelaksanaan kegiatan ini dapat disarankan agar program budidaya tanaman kakao dapat dilaksanakan secara berkelanjutan, hingga terbentuk suatu kelompok yang khusus menangani coklat, peserta penyuluhan juga berharap agar dapat diberikan pembinaan dan pendampingan terus dan tidak hanya sampai terbatas pada kegiatan ini saja. Selain itu, peserta juga berharap dapat dikembangkan untuk tanaman lainya seperti tanaman kopi karena kopi juga banyak ditemukan di daerah tersebut.

\section{UCAPAN TERIMAKASIH}

Penulis mengucapakan terima kasih yang tidak terhingga kepada ketua Lembaga Penelitian dan Pengabdian kepada masyarakat Universitas Mataram, Dekan Fakultas Pertanian dan Rektor Universitas Mataram atas dukungan dana dan fasilitas yang diberikan.

\section{DAFTAR RUJUKAN}

Armengot, L., Ferrari, L., Milz, J., Velásquez, F., Hohmann, P., \& Schneider, M. (2020). Cacao agroforestry systems do not increase pest and disease incidence compared with monocultures under good cultural management practices. Crop Protection. https://doi.org/10.1016/j.cropro.2019.1
05047

Bélanger, R. R., Benhamou, N., \& Menzies, J. G. (2003). Cytological evidence of an active role of silicon in wheat resistance to powdery mildew (Blumeria graminis f. sp. tritici). Phytopathology.

https://doi.org/10.1094/PHYTO.2003.9 3.4.402

Fallis, A. . (2013). Analisis Teknik Pemngkasan, Pemupukan, Panen Sering dan Sanitasi (P3S) terhadap Produktivitas dan Pendapatan Usaha Tani Kakao (Theobroma cacao L.) di Kabupaten Pinrang, Bantaeng dan Luwu Timur. Journal of Chemical Information and Modeling.

Firmansyah, M. A. (2010). Rekomendasi Pemupukan Umum Karet, Kelapa Sawit, Kopi dan Kakao. Litbang.

Hawa, S., Abdullah, \& Usman. (2015). Sistem Pakar Diagnosa Penyakit Pada Tanaman Kakao Menggunakan Metode Forward Chaining (Studi Kasus Dinas Perkebunan Indragiri Hilir). Sistemasi.

Indriani, D., \& Chanan, M. (2011). Pendampingan Pengendalian Hama Terpadu Dan Penanganan Pasca Panen Kakao Pada Kelompok Tani Kakao Desa Mentaraman Kecamatan Donomulyo Kabupaten Malang. Jurnal Dedikasi.

Khaerana, K., \& Gunawan, A. (2019). Pengaruh Aplikasi Pupuk Silika dalam Pengendalian Tungro. Jurnal Pertanian. https://doi.org/10.30997/jp.v10i1.1687

Lestari, W., Syarief, R., \& Sumantadinata, K. (2013). Strategi Peningkatan Daya Saing Kakao Indonesia Di Pasar Internasional. Manajemen IKM.

Rosada, I. (2016). Aplikasi Pupuk Organik Melalui Pemanfaatan Limbah Kulit Kakao (POD) Pada Kebun Kakao Di Kecamatan Rilau Ale Kabupaten Bulukumba. Jurnal Balireso: Jurnal Pengabdian Pada Masyarakat. https://doi.org/10.33096/balireso.v1i1.7

Rubiyo, \& Siswanto. (2012). Improvement and development production of cocoa in Indonesia. Journal of Industrial and Beverage Crops.

Saloko, S., Santoso, B. B., Hadi, A. P., \& Hadi, A. P. (2018). Pengembangan Agrowisata Kampung Coklat Senara Kabupaten Lombok Utara Pra Dan Pasca Bencana Alam. Prosiding Konferensi Nasional Pengabdian Kepada Masyarakat Dan Corporate 
Social Responsibility.

Tresliyana, A., Fariyanti, A., \& Rifin, A. (2004). Daya Saing Kakao Indonesia Di Pasar Internasional. Jurnal Manajemen Dan Agribisnis.

https://doi.org/10.17358/jma.12.2.150

Tutiliana, T. (2016). Teknik dan Manfaat Pemangkasan Pada Tanaman Kakao (Theobroma cacao. L.) Di Gampong Blang Mane Kecamatan Peusangan Selatan. Jurnal Edukasi Dan Sains Biologi.

Winarsih, S. (1990). Preliminary research of the effect of shading and pruning on cocoa production. Pelita Perkebunan (a Coffee and Cocoa Research Journal).

https://doi.org/10.22302/iccri.jur.pelitap erkebunan.v6i2.367

Yukamgo, E., \& Yuwono, W. (2007). Peran Silikon Sebagai Unsur Bermanfaat Pada Tanaman Tebu. IImu Tanah Dan Lingkungan. 